\title{
The relationship of the Intolerance of uncertainty and worry and metacognitive beliefs in people with depressive symptoms
}

\author{
Ghasem Abdolpour ${ }^{1}$, Touraj Hashemi ${ }^{2}$, Mohammad Reza Shairi ${ }^{3}$, Fereydoon Alizadeh ${ }^{4}$ \\ 1- Ph.D. Psychology, Shahed university, Tehran, Iran (Corresponding Author) \\ 2- Ph.D. Psychology, Tabriz university, Tabriz, Iran \\ 3- Ph.D. Psychology, Shahed university, Tehran, Iran \\ 4- MA. Psychology, Tabriz Branch, Islamic Azad University, Tabriz, Iran
}

\begin{abstract}
Introduction: Depression is one of the most prevalent and disabling psychological disorders. The present study aims to relationship between intolerance of uncertainty and worry and metacognitive beliefs in people with symptoms of depression.
\end{abstract}

Aim: The present study aims to relationship between intolerance of uncertainty and worry and metacognitive beliefs in people with symptoms of depression.

Method: The research method in terms of purpose is Basical and in terms of implementation method is descriptive- relationship. The study population consists of all patients with depression, psychiatric clinic of Tabriz.The sample consists of 40 patients with major depression who were selected through convenience sampling method. The Standard data collection tools in this research are Metacognitive beliefs of the questionnaire, Pennsylvania concerns a questionnaire and intolerance of uncertainty questionnaire.

Results: Statistical data analysis using multiple regression analysis was used. The results showed that the intolerance of uncertainty and worry and metacognitive beliefs in depressed patients there was a significant positive correlation. Multiple regression analysis showed that the structures IU and beliefs could explain $45 \%$ of the changes concern.

Conclusion: This study is consistent with results of previous studies suggest that taking IU and beliefs in education programs and psychological interventions can prevent emotional disorders, reduction and effective treatment.

Keywords: depression, anxiety, intolerance of uncertainty, beliefs. 


\title{
رابطه عدم تحمل بلاتكليفى و باورهاى فراشناختى با نكر انى در افراد مبتلا به نشانههاى افسردىى
}

\author{
قاسم عبدل يور'، تورج هاشمى'، محمد رضا شعيرى'، فريدون عليز ادهء

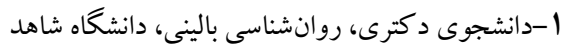 \\ r- rهيات علمى، روانشناسى، دانشگاه تبريز \\ r- هيات علمى، روانشناسى، دانشكاه شاهد \\ ع-دانشجوى كارشناسى ارشد، روانشناسى، دانشگاه آزاد تبريز
}

جكيده

مقدمه: افسردكى يكى از شايعترين و ناتوان كنندهترين اختلالات روانشناختى است. هدف يُزوهش حاضر بررسى رابطه عدم

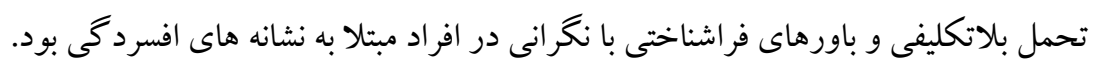

هدف: هدف يزٔوهش حاضر بررسى رابطه عدم تحمل بلاتكليفى و باورهاى فراشناختى با نخرانى در افراد مبتلا به نشانهاى افسردگى بود.

روش: روش يزوهش با توجه به هدف بنيادى و از لحاظ روش اجرا از نوع توصيفى-همبستكى است. جامعه آمارى شامل كليه

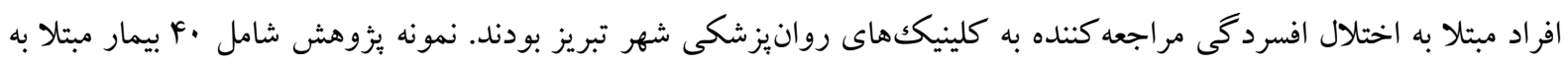

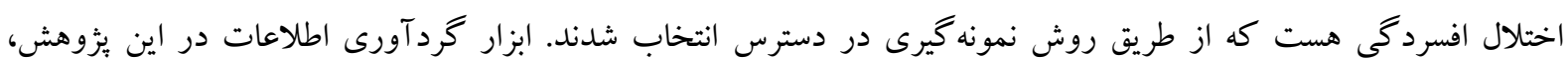

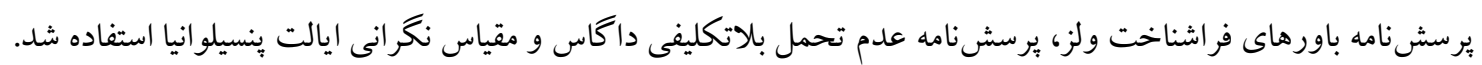

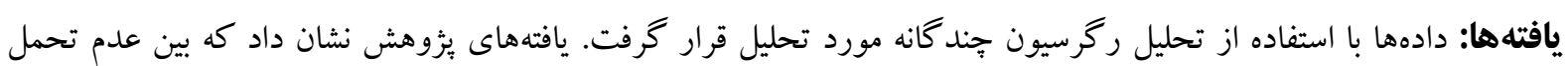

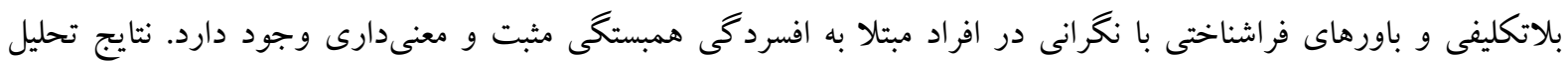

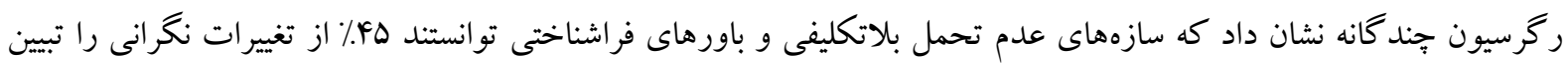

نتيجه كيرى: نتايج اين بُزوهش همسو با نتايج تحقيقات بيشين، نشان مىدهد كه در نظر كرفتن عدم تحمل بلاتكليفى و باورهاى

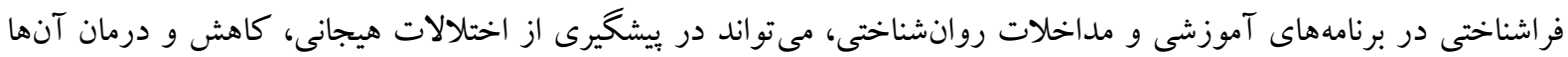
مؤثر باشد. كليد وازهها: افسردگى، نگر انى، عدم تحمل بلاتكليفى، باورهاى فراشناختى 
زاى احتمالى و بيامدهاى بالقوه فاجعه انكيز آن ها

است (ديوى و ولز (1999،).

توضيح اينكه، عينىترين كنش ورى نكرانى، تلاش سودمند براى حل مشكلات روانى است، اكرجه ممكن است اين تلاش بـ حاصل باشد. ديوى و ولز بر اين باورند كه نظخرانى ساز گار و

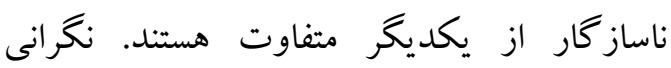
ساز گار در راستاى حل مسئله است و رفتار متمر كز بر حل مسئله را در بيى دارد. در صورتى كه نكخرانى ناساز كار، دامنه تكرار شوندهاى از نتايج منفى رابه دابه دنبال دارد و شخص سعى مى كند، راهبردهاى مقابلهاى را تا زمان رسيدن به برخى هدفهاى

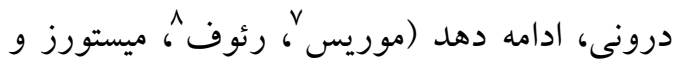

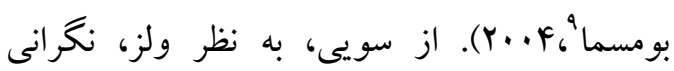
مزاحمت ايجاد مى كند اما قابليت كنترل دارد و يكك راهبرد مقابلهاى است كه مىتواند مركز

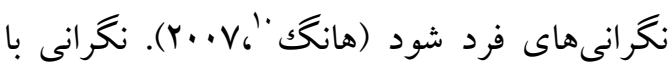
بسيارى از شاخص هاى ناساز گار روان شناختى در بزرگكسالان ازجمله افسردگى و اضطراب بالينى

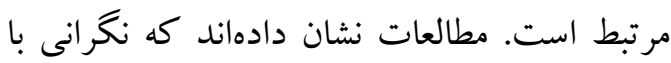
افزايش خطر بروز اختلالات روانى، اختلالات اجتماعى و شغلى، افزايش استفاده از خدمات بهداشتى و مشكلات جسمانى در جامعه همراه

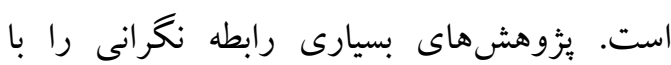

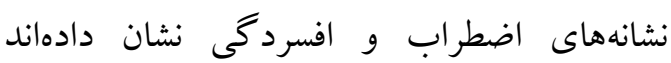

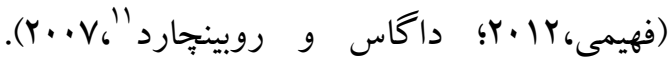
نخر انى در تداوم عاطفه منفى و آسيب مهارت هاى دوبنهارد

${ }^{6}$ Davey\& Wells

${ }^{7}$ Muris

${ }^{8}$ Roelofs

${ }^{9}$ Meesters \& Boomsma

${ }^{10}$ Hong

${ }^{11}$ Dugas \& Robinchaud
اختلال افسردگى اساسى يكى از انواع اختلالات هيجانى است كه مؤلفه اصلى آن اندوه است. افراد مبتلا به افسردگى، خلق خود را بهصورت غمخين و درمانده توصيف مى كنند. بىعلاقكى يا فقدان احساس لذت تقريباً هميشه و دست كم تاندازهاى وجود دارد و هيج جيز توجه آنان را جلب نمى كند

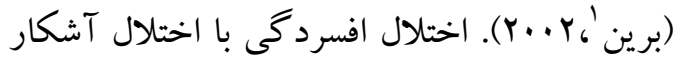

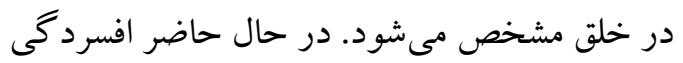
جهارمين بيمارى شايع در جهان محسوب مىشود

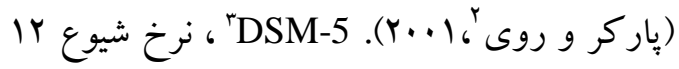

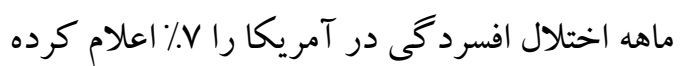

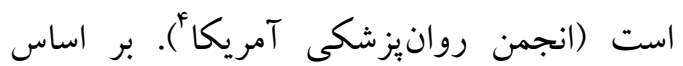
مطالعاتى كه در ايران توسط صادقى و همكارانش

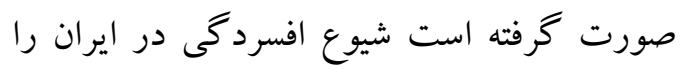
هץ\% بر آورد كردهاند كه احتمال وجود آن در زنان

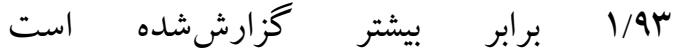

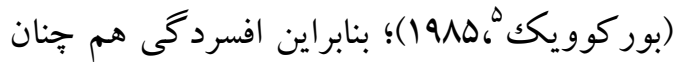

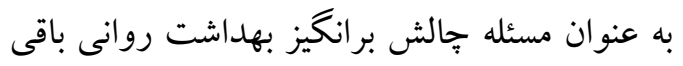
است. به طورى كه شيوع بالاى افسردگى، موجب شده كه يزوهشخ ان عوامل مرتبط با اين مشكلات را موردتوجه قرار دهند. ازجمله اين عوامل مىتوان

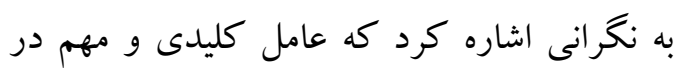

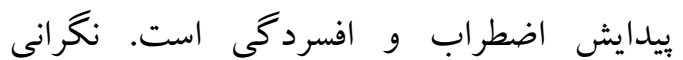
بهعنوان فرايند شناختى بيشبينى خطر و تهديد است كه شامل افكار و تصاوير تكرارشونده،

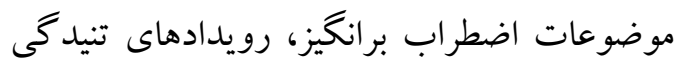

\footnotetext{
${ }^{1}$ Brain

${ }^{2}$ Parker \& Roy

${ }^{3}$ Diagnostic and Statistical Manual of Mental

Disorders(5th)-DSM-5

${ }^{4}$ American Psychiatric Association

${ }^{5}$ Borkovec
} 
اجتناب شناختى تأثير مى گذارد؛ بنابراين، افراد با

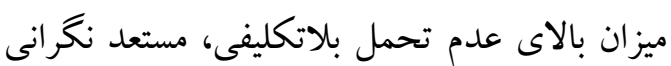

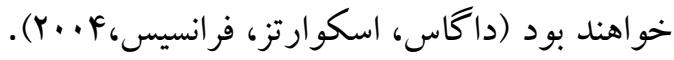

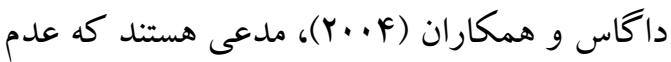
تحمل بلاتكليفى بهترين بيش بينى كننده نكرانى در جمعيتهاى بالينى و غير بالينى است؛ آنها

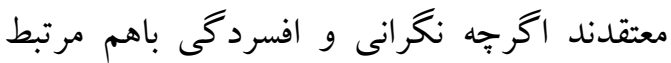
هستند، اما بررسى رابطه بين عدم تحمل بلاتكليفى

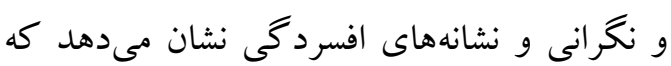
عدم تحمل بلاتكليفى در سطح بالايى با نخرانى

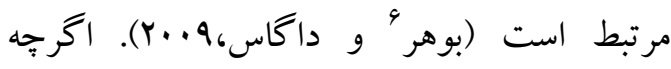
يثوهش هاى بيشين، متمركز بر اختصاصى بودن

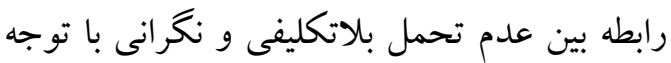
به اضطراب بوده است، شايد بررسى اختصاصى

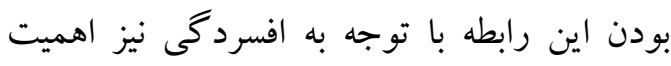
ويزه اى داشته باشد. در حقيقت شواهد قابل توجهى وجود دارد كه نشان مى دهد، اختلال

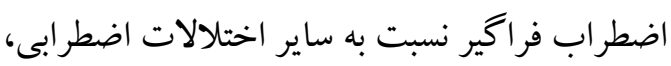
رابطه تنگاتنگى با افسردگى دارد. براى نمونه اخر جه اختلالهاى اضطرابى نامتجانس هستند، اختلال

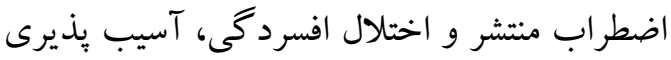
ارثى مشابهى دارد. يافته هاى مطالعههايى كه از مدلسازى ساختارى استفاده كردهاند نشان مىدهد كه عاطفه منفى كلى، واريانس بزرگت ترى را در

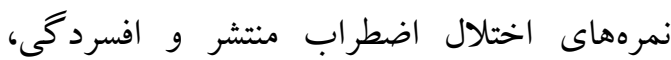

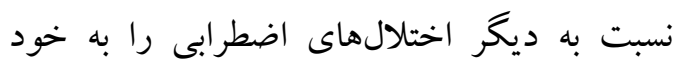
اختصاص مى دهد (بوهر و داكاس، 9. +Y). شواهد قابلتوجهى وجود دارد كه نشان مىدهد عدم تحمل بلاتكليفى عامل آسيبيذيرى شناختى

${ }^{6}$ Buher
شناختى درگير است (ارفعى، بشارت، قليزاده و حكمتى، (Y) (Y)

يكى از سازههاى مرتبط با نكرانى، عدم تحمل بلاتكليفى است كه به طور گسترده به عنوان واكنش شناختى، هيجانى و رفتارى به عدم اطمينان

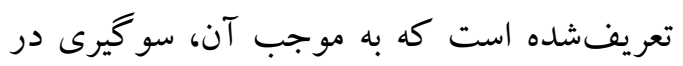
يردازش اطلاعات و افزايش ارزيابى معيوب تهديد و كاهش كنار آمدن، رخ مى دهد (داگاس،

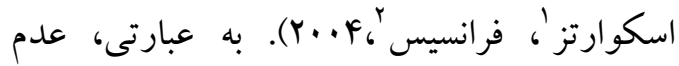
تحمل بلا تكليفى يكك ويزگ شخى شصيتى است كه از مجموعه ایى از عقايد منفى درباره عدم قطعيت تشكيل شده است. براى مثال افرادى كه عدم تحمل بلاتكليفى دارند، معتقدند كه بلاتكليفى، بـاكي، بريشان كننده است. وجود شكك وترديد در مورد آينده غيرقابل تحمل است، وقايع غيرمنتظره منفى هستند و بايد از آن ها اجتناب كرد، شكك و ترديد

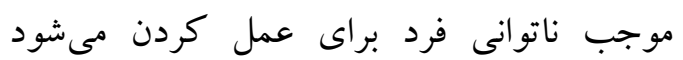

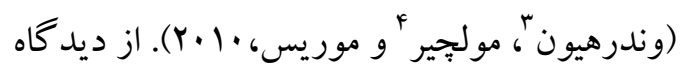

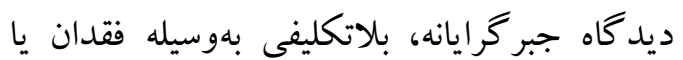

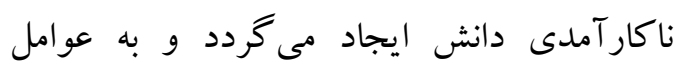
درونى مربوط است كه فرد قادر به كنترل آن

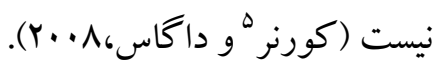
داكاس و همكاران نشان دادند كه عدم تحمل

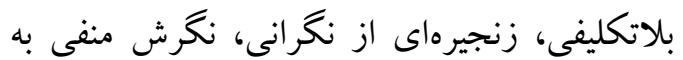

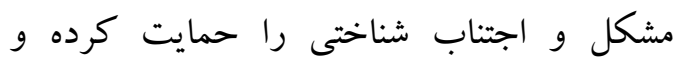
همجهنين بيان كردهاند كه عدم تحمل بلاتكليفى بهطور مستقيم بر نخرش فرد به مشكل و سطوح

\footnotetext{
${ }^{1}$ Scewartz

${ }^{2}$ Francis

${ }^{3}$ Van der Heiden

${ }^{4}$ Melchoir

${ }^{5}$ Korner
} 
برنامهريزى و تشخيص خطاها در عملكرد، اشاره مى كند (براون، برانسفورد و فرارا، بهو ().

انگاره اصلى در اين رويكرد اين است كه باورها در اختلالهاى روانشناختى از مؤلفههاى روانشناختى تشكيل مىشود كه كنش ورى تفكر

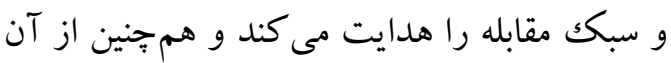

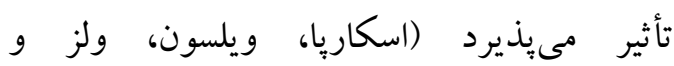

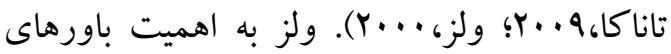
فراشناختى هم در فرايند نكرانى و هم در محتواى

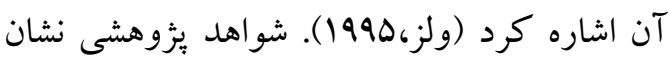
مى دهند كه باورهاى فراشناختى منفى در مورد غيرقابل كنترل بودن و خطر نغرانى بهطور

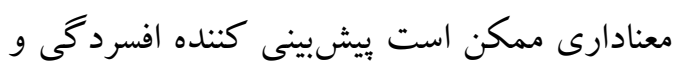
اضطراب باشد. درواقع بين باورهاى فراشناختى و

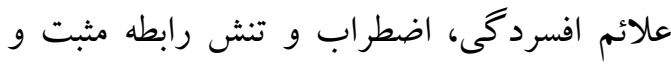

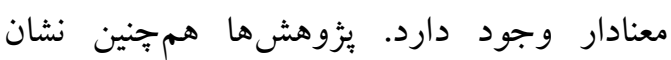
مىدهند باورهاى فراشناختى منفى و مثبت ممكن است سبب تداوم نكرانى شود (ولز، 1999). نتايج

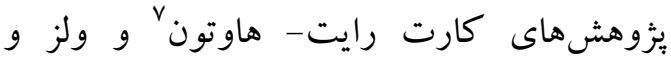

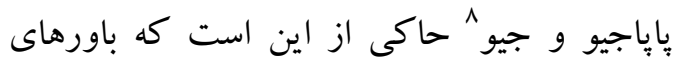
فراشناختى، رابطه مثبت و معنادارى با استعداد فرد در برابر نكر انى آسيب شناختى دارد. با توجه به اين

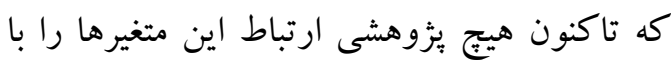

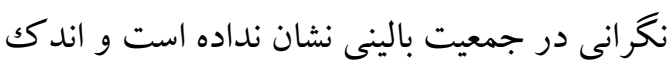
يخوهشهاى انجامشده هم بر روى جمعيت غير بالينى صورت گرفته است؛ لذا هدف اين بثروهش، تعيين رابطه عدم تحمل بلاتكليفى و باورهاى

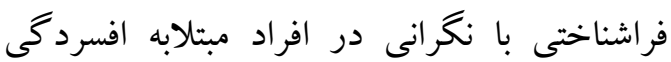

$$
\text { اساسى هست. }
$$

${ }^{7}$ Cartwright-Hatton

${ }^{8}$ Papageorgiou

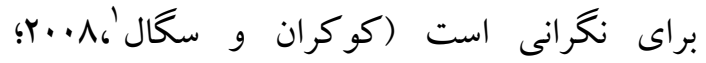

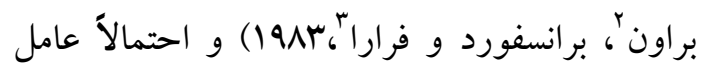
مهم تداوم بخش اختلال اضطراب فراگير است

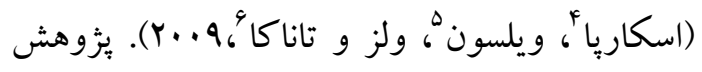
يُوهش ها نشان داده است كه عدم تحمل بلاتكليفى

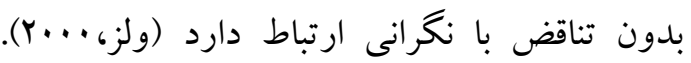
مطالعه هاى تجربى نيز رابطه قابل اطمينانى بين عدم

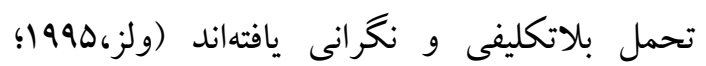
اسكاريا، ويلسون، ولز و تاناكا،9 +. (Y).

يكى ديخر از نظريههايى كه به تبين نخرانى برداخته است، نظريه فراشناختى است. فراشناخت، به ساختارها، دانش و فرايندهاى روانشناختى اشاره مى كند كه با كنترل، تعبير و تفسير افكار و و

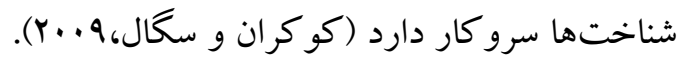
اكثر فعاليت هاى شناختى به عوامل فراشناختى وابستهاند. علاوه بر اين، اطلاعاتى كه از بازبينى

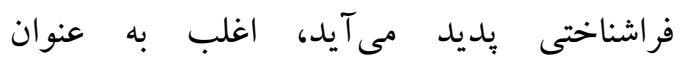
احساسهاى ذهنى تجربه مىشوند كه مىتواند بر

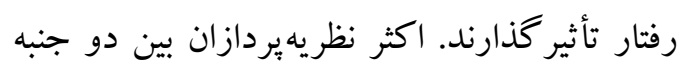
فراشناخت يعنى دانش فراشناختى و و تنظيم فراشناختى تمايز قائل شدهاند. در اين راستا، دانش فراشناختى شامل اطلاعاتى است كه افراد در مورد شناخت خود و در مورد عوامل مرتبط با تكليف يا راهبردهاى ياد گيرى كه در آن تأثير مى گذارند،

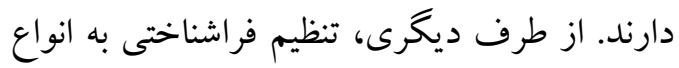
اعمال اجرايى نظير توجه، بازبينى، كنترل،

\footnotetext{
${ }^{1}$ Corcoran \& Segal

${ }^{2}$ Brown

${ }^{3}$ Bransford \& Ferrara

${ }^{4}$ Scarpa

${ }^{5}$ Wilson

${ }^{6}$ Tanaka
} 
مقياس علدم تحمل بلأكليفي: اين مقياس توسط

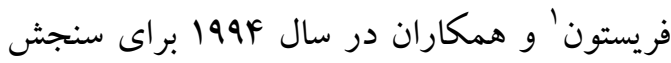
ميزان تحمل افراد در برابر موقعيت هاى نامطمئن و حاكى از بلاتكليفى، طر احى شده است. اين مقياس از TV آيتم تشكيلشده است كه آزمودنىها بر بر بـ

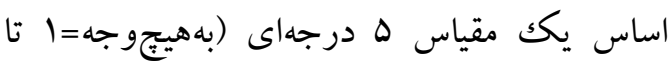

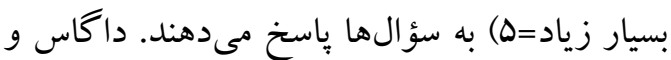
بوهر ب ضريب آلفاى كرونباخ به دست آمده براى

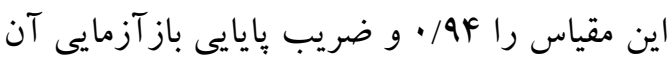

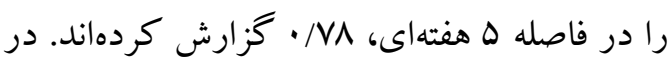
يثزوهش حميد يور و اندوز آلفاى كرونباخ برابر M M • و و يايايى باز آزمايى در فاصله ب هفتهاى برابر

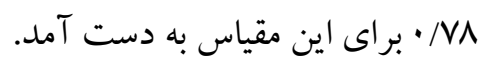

مقياس نترانى 'يالت پينسيلوانيا: برسشنامه نخرانى

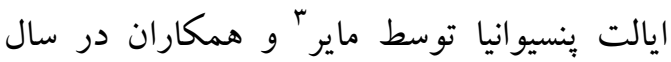
199 ساختهشه است. اين برسشنامه 19 ايتم دارد. آزمودنى به اين سؤالها بهصورت كاملاً

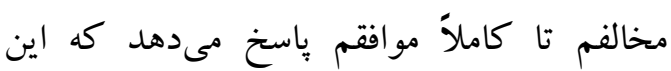

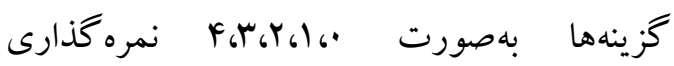
مىشوند. 11 ماده آن مربوط به وجود نكرانى به طور مثبت نمره گذارى مىشوند و ه هاده ماده آن

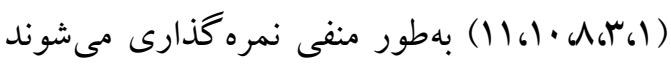

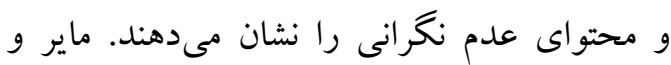
ديخران آلفاى كرونباخ به دست آمده را براى اين

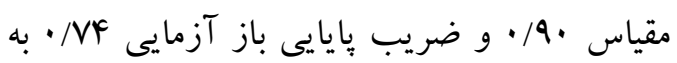

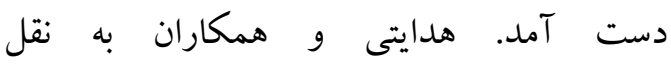

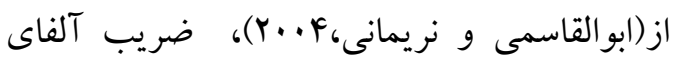

${ }^{1}$ Freeston

${ }^{2}$ Buher

${ }^{3}$ Mayer
مطالعه حاضر با توجه به هدف از نوع بزوهشهاى بنيادى و ازنظر شيوه جمع آورى دادهها از نوع همبستگى بود. جامعه آمارى بثزوهش شامل كليه

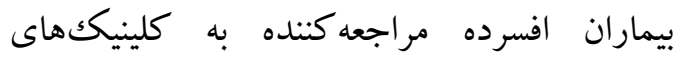
روانيزشكى شهر تبريز بود كه توسط روانيزشك

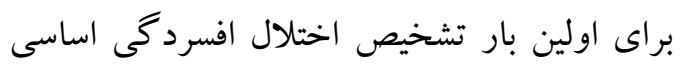
دريافت كردهاند. نمونه موردمطالعه ·9 بيمار مبتلا به اختلال افسردگى اساسى بود كه بهصورت نمونه گيرى در دسترس انتخاب شدند. افراد گروه نمونه بر اساس ملاككهاى ورود سن · ب تا هله سال، داشتن تحصيلات حداقل تا بِايان كلاس بنّجم ابتدايى، عدم مصرف داروهاى ضدافسردگى هنگام اجراى برسشنامه هاى بثزوهش و يا عدم اتمام

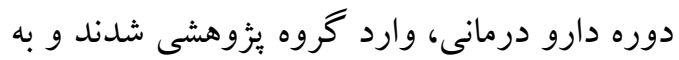
وسيله ملاككهاى خروج از قبيل سابقه مانيا

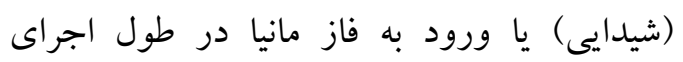
يزٔوهش و مصرف داروهاى ضدافسردگى هنگام اجراى يرسشنامها از ئزوهش خارج شدند. بعد از

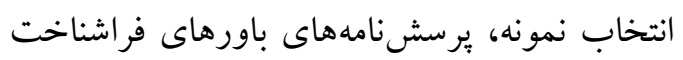

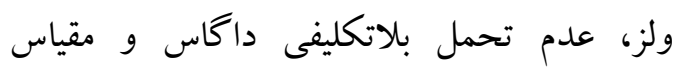
نكرانى ايالت بنسيلوانيا در اختيار آنها قرار داده

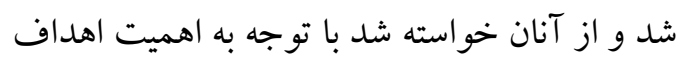
تحقيق، اطلاعات خواستهشده را با دقت و صداقت در يرسشنامه درج نمايند. بيش از بـ تكميل يرسشنامها در مورد اهداف يثزوهش توضيحاتى به شر كت كنند گان ارائه شد و به آنها اطمينان داده شد كه ياسخهايشان بهصورت محرمانه خو اهد ماند و بدين ترتيب رضايت آنها براى شركت در

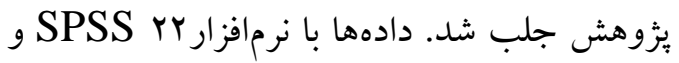
روش رگرسيون جند گانه همزمان تحليل شدند. 
خود آكاهى شناختى، باورهاى منفى در مورد كنترل نايذيرى افكار و و خطر و و باورهايى مانى فراشناختى عمومى منفى در موردنياز به كنترل

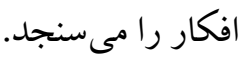

كرونباخ را به ترتيب 91/ • و 191 • اعلام كردهاند. فرم كوتاه برسشنامه فراشناخت: بهمنظور سنجش باورهاى فراشناخت ساختهده است. اين برسشنامه ·r ماده دارد و هر آزمودنى بهصورت جهار گزينهاى (1= موافق نيستم تا ع= خيلى موافقم) باسخ مىدهد. اين يرسشنامه ينج مؤلفه اعتماد

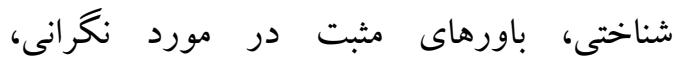

يافته ها

شاخصهاى توصيفى متغيرهاى موردمطالعه ارائه شده است. جدول 1: شاخصهاى آمار توصيفى

\begin{tabular}{|c|c|c|}
\hline انحراف معيار & ميانكين & متغير \\
\hline Q/Vr & $V I / F V$ & عدم تحمل بلاتكليفى \\
\hline $\mid H / F A$ & $V Y / F q$ & باورهاى فر اشناخت \\
\hline$I Y / T$ & $91 / 1 r$ & نغر انى \\
\hline
\end{tabular}

تحمل بلاتكليفى داراى ميانگين VI/FV و نخرانى

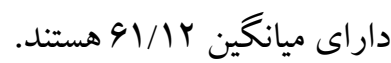

جدول ا نشان مىدهد كه از بين متغيرهاى

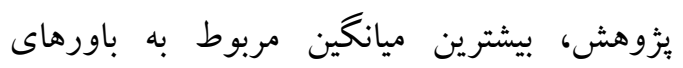

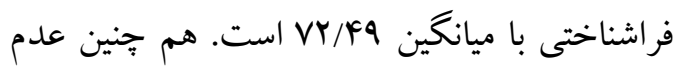

جدول r- ماتريس همبستغى متغير هاى بيش بين با نتر انى

\begin{tabular}{|c|c|c|}
\hline سطح معنى دارى & ضريب همبستغى & متغير \\
\hline$\cdot / \cdots 1$ & $\cdot / \Delta \cdot V$ & عدم تحمل بلاتكليفى \\
\hline.$|\cdots|$ & $.19 \mathrm{Vr}$ & باورهاى فراشناختى \\
\hline
\end{tabular}

مندرجات جدول ب نشان مىدهد بين عدم تحمل درو راستاى تعيين نقش متغيرهاى بيشبين در

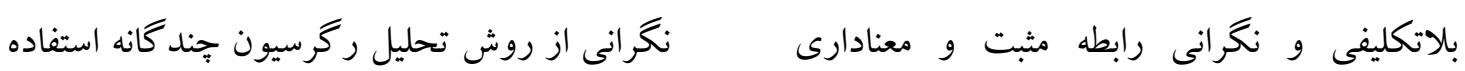

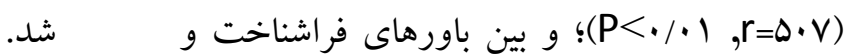

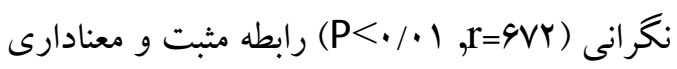

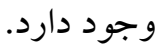
جدول r- تحليل رترسيون همزمان متغيرهاى بزوهش

\begin{tabular}{|c|c|c|c|c|c|c|c|}
\hline $\mathbf{R 2}$ & $\mathbf{R}$ & معنى دارى & $\mathbf{F}$ & مجانكين & دراجه & مجذمورات & ركز مدل \\
\hline \multirow[t]{2}{*}{ - /FAG } & $.19 V 0$ & $\cdot / \cdots \cdot 1$ & $\mid \theta / 4 \lambda$ & 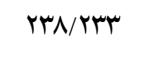 & r & FVG/FG & ركرسيون \\
\hline & & & & ID/rAY & r & $\Delta 99 / 1 \mu r$ & باقيمانده \\
\hline
\end{tabular}


از طرفى بين متغيرهاى باورهاى فراشناخت و عدم

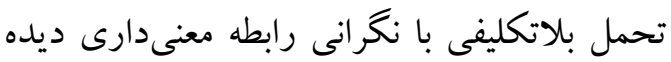

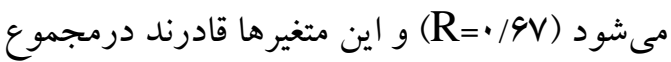
(R2=•/Fa)
با توجه به نتايج تحليل واريانس و شاخصهاى

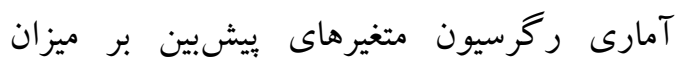

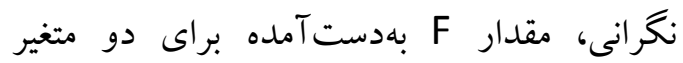
باورهاى فراشناخت و عدم تحمل بلاتكليفى $\mathrm{P}(<\cdot / \cdot 1, \mathrm{~F}=\mid \Delta / 4 \Lambda)(\mathrm{N})$

\begin{tabular}{|c|c|c|c|c|c|c|}
\hline \multicolumn{7}{|c|}{ جدول ع- خلاصه تحليل واريانس و ركر سيون متغير هاى بيشبين با نكرانى } \\
\hline سطح معنى دارى & $\mathbf{F}$ & $\mathbf{R}$ & $\mathbf{t}$ & Beta & B & متغير \\
\hline.$/ \cdot 1$ & $\mid r / M V$ & $\cdot / T \Delta V$ & $r / 9 Y$ & $\cdot / 0.9$ & $\cdot / 4 \cdot 1$ & 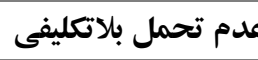 \\
\hline.$/ . .1$ & $11 / 94$ & $\cdot / \pi Y$ & $r / A q$ & $\cdot / \Delta \mathrm{VV}$ & . & باورهاى فراشناخت \\
\hline
\end{tabular}

مندرجات جدول F نشان مىدهد كه عدم تحمل بلاتكليفى هץ/• درصد و باورهاى فراشناختى،Yr/· درصد از ميزان

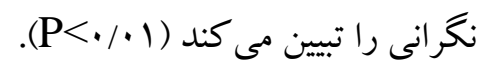

تحمل بلاتكليفى و نغرانى با افسردگى باشد (بوهر و

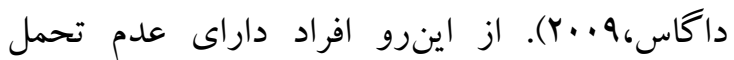
بلاتكليفى بالا، مستعد تجربه سطح بالاى نخر انى هستند.

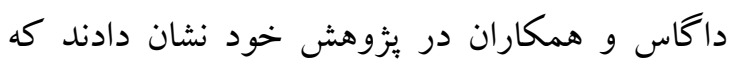
شركت كنند كان با سطوح بالاى عدم تحمل بلاتكليفى اطلاعات مبهم را تفسيرهاى تهديدآميز كردند

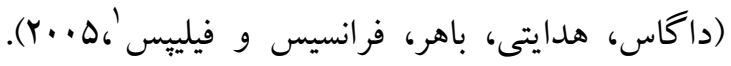

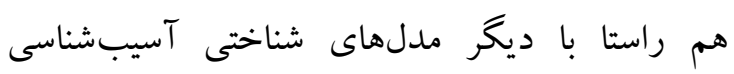
روانى، مدل عدم تحمل بلاتكليفى داگاس مبتنى بر اين ايده است كه باورها در مورد عدم تحمل بلاتكليفى، زمانى كه افراد در حالت خلقى منفى قرار دارد، بهطور كامل فعال است. بهطور خلاصه مىتوان بيان داشت افرادى كه داراى

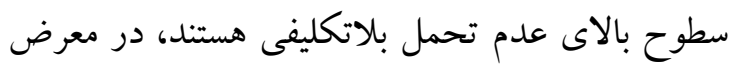
خطر مبتلا شدن به اختلالهاى اضطرابى و خلقى هستند؛ زيرا آنها گرايش به خلق تفسيرهاى تهديدآميز

\section{بحث و نتيجه كيرى}

هدف از انجام ئزوهش حاضر تعيين رابطه عدم تحمل بلاتكليفى و باورهاى فراشناختى با نخر انى بود. يكى از

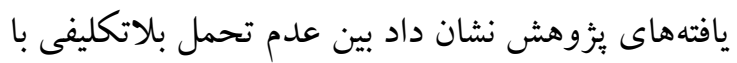
نكرانى ارتباط مثبت دارد كه اين نتايج با نتايج

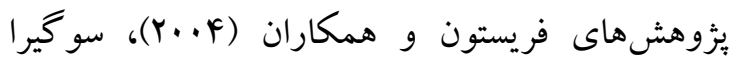
(Y.人) تحقيقى كه داكاس و همكاران انجام دادند يافتها نشان داد كه بين عدم تحمل بلاتكليفى با نمرات افسردگى

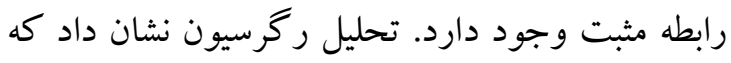

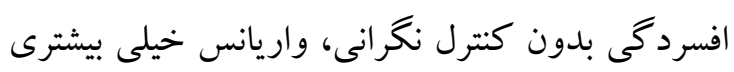
از عدم تحمل بلاتكليفى را نسبت به كنترل نكرانى بلى تبيين مى كند. يكك تبيين احتمالى براى اين يافته اين

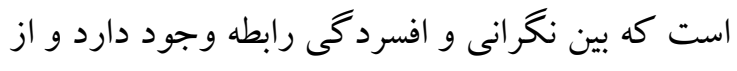

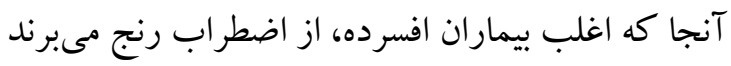
بنابراين وجود شباهت بين افسردگى و اضطراب مىتواند يكك تبيين احتمالى براى وجود رابطه بين عدم

${ }^{1}$ Phillips 
تحليل رگرسيون، باورهاى فراشناختى بيشتر از عدم تحمل بلاتكليفى قادر است واريانس نخرانى را تبيين كند. در تبيين اين نتايج مى توان بيان داشت كه باورهاى

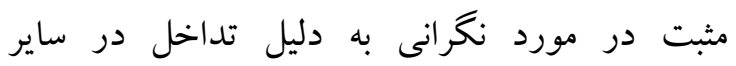

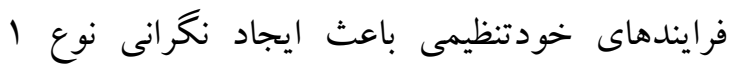

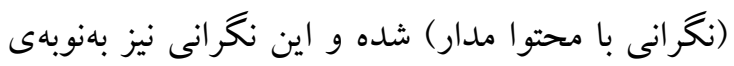

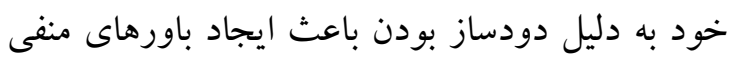

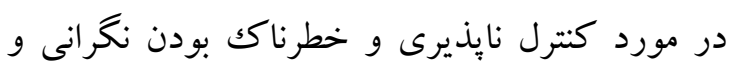
درنهايت ايجاد نخرانى نوع ب (نكرانى در مورد نخر انى) مىشوند. رفتارهاى مقابله ازجمله اجتناب از افكار مزاحم، توجه بركردانى و همجهنين فرونشانى افكار

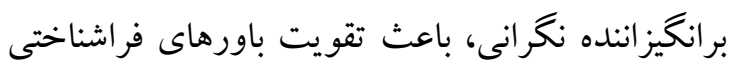
مثبت و منفى و درنتيجه افزايش هر جه بيشتر نخرانى براني

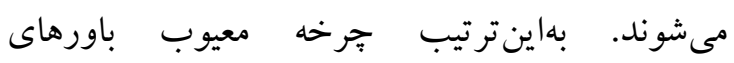
فراشناختى و نكرانى تداوم مىيابد (ولز، 1990).

در تبيين اين يافتها مىتوان اظهار داشت، طبق مدل

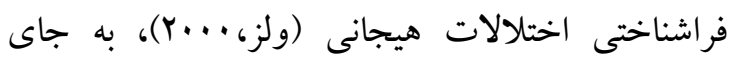

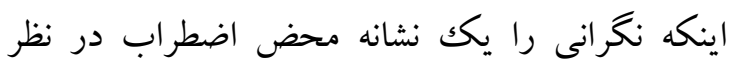
بحيرد، تأكيد شده است كه افراد باورهاى مثبتى را در

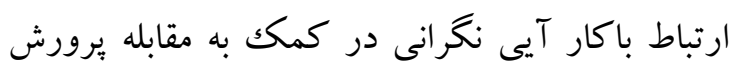

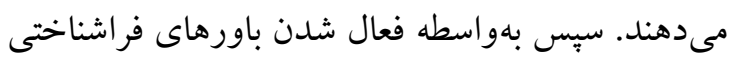
مبتنى بر غيرقابل كنترل بودن و خطر، نوع ديخرى از نكر انى تحت عنوان فر انكرانى در آنها شكل مئى گيرد. فرانگرانى موجب برانگيختن و واكنشهاى جسمانى

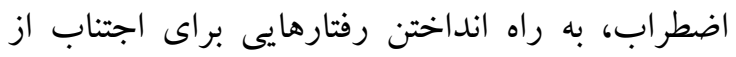
موقعيتهاى تهلديد آميز و راهبردهايى براى كنترل فكر

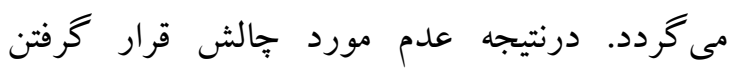
باورهاى كنترل نايذيرى و خطر و نيز عدم مواجهه با بإن شواهد اخلاقى كه ثابت مى كنند نخرانى قابل كنترل،

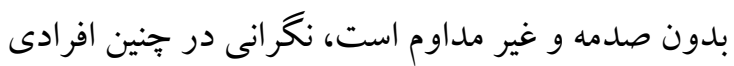

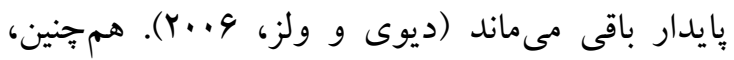

از اطلاعات مبهم و ايفاى نقش ضعيف در موقعيتهاى با ابهام متوسط هستند. طبق مدل عدم تحمل بلاتكليفى افراد مضطرب، موقعيتهاى نامعين و يا مبهم را فشار آور و آشفته كننده دركك مى كنند و درنتيجه در باسخ موريخ به جنين موقعيتهايى، نظخرانى مزمنى را تجربه مى كنند.

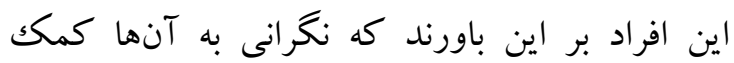

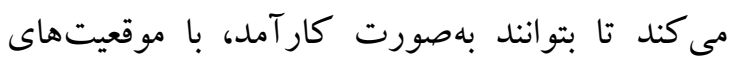
ترس آور مقابله كنند و يا از اين طريق مانع وقوع جنين حوادثى شوند. اين افراد هم جنين وجود موقعيتهاى مبهم و منفى احتمالى را غيرقابلقبول مىدانند؛ و وقتى

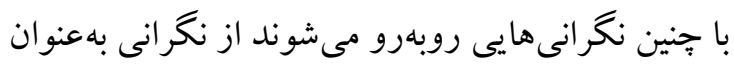
راهبرد اصلى براى كاهش سطوح بالاى عدم تحمل بلاتكليفى خود استفاده مى كنند كه اين موضوع برائ نشاندهنده رابطه تنگاتنگ عدم تحمل بلاتكليفى با بان

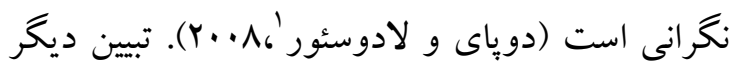

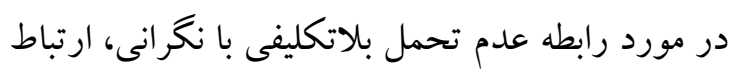
آن با مفهوم كنترل شخصى است. كنترل شخصى، بنيان شناختى براى سلامتى فراهم كرده و از ميزان اضطرابى كه تجربه مىشود، مى كاهد. موقعيت هاى غيرقطعى و مبهم مى توانند به اين باور منتهى شوند كه هيجيك از ياسخهاى فرد نمىتو اند ييامدهاى آينده را كنترل كند.

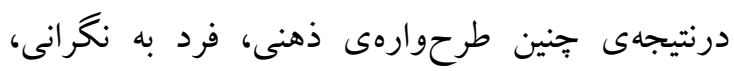

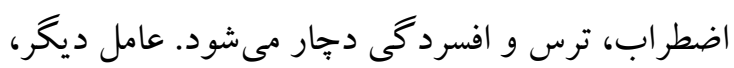
ييشبينى بذيرى محرك يا موقعيت است. ايمنى،

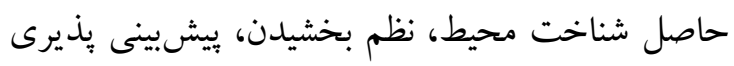

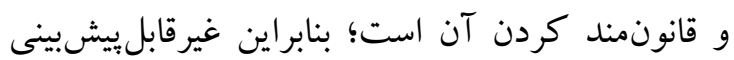
بودن يكك محرك يا موقعيت موجب ايجاد حس نامنى

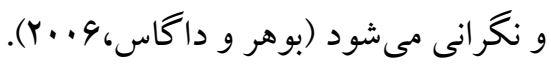
همجزنين در اين يزوهش بين فراشناخت و نيخرانى رابطه

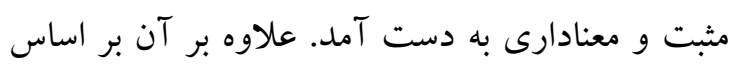




$$
\text { لحيشنهاد مى شود در يزوهش هاى بعدى اين موارد مورد }
$$

$$
\text { تشكر و قدردانى }
$$

از تمامى افرادى كه با تكميل كردن برسشنامهها ما را

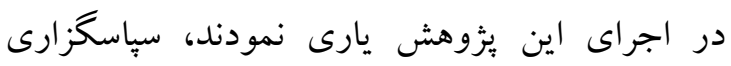
مىنماييم و يادآور مىشويم طرح فوق بدون حمايت

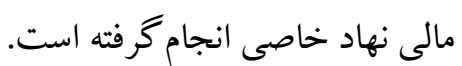

\section{References}

Abolghasemi A, Narimani M.)2006). Psychological tests. Ardebil: Rezvan bagh; 111:275.

American Psychiatric Association(2013). Diagnostic and statistical manual of mental disorders. 5th ed. (DsM-5). Washington, DC: Author.

Arfaei A, Besharat gharamlaki R, Gholizadeh $\mathrm{H}$, Hekmati E.(2011). Intolerance of uncertainty: comparision between individuals with Major depressed disorder with obsessive-compulsive disorder. J Tabriz Univ Med Sci. 5: 17-22. [Persian].

Artino, Jr. A. R. (2008). Learning online: understanding academic success from a selfRegulated learning perspective, Unpublished Doctoral Dissertation, Connecticut University.

Borkovec, T. D. (1985). Worry: A potentially content.Behaviour Research and Therapy, 23 (11), $481-482$.

Brain, C. (2002). Advance psychology: Application, issues and perspective, London: Nelson thorenes.

Brown AL, Bransford JDC, Ferrara RA.(1983). Learning remembering and understanding.In J. Flavell and E. Markman (Eds). Handbook of child psychology: vol.3, cognitive development. New York: willey.

Buher k, Dugas MJ.(2004). The intolerance of uncertainty scal: psychometric property Of the English version. Behav Res Ther; 28: 835842.

Buher K, Dugas MJ.(2006). Investigation the construct validity of intolerance of uncertainly and its unique relationship with worry. J Anxiety Disorder, 20: 223-234.

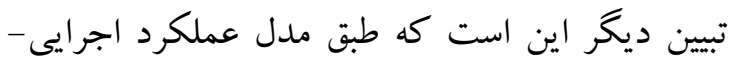

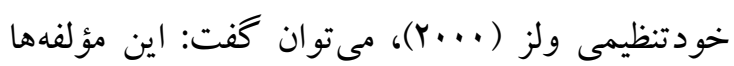
باعث فعال شدن نشانكان شناختى - توجهى مى شوند. بنابراين، فر آيند خودتنظيمى را دجار سو گيرى نموده و

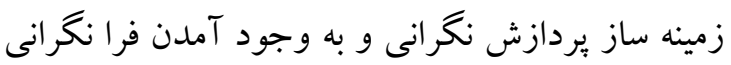
مىشود. فعال شدن فرا نخرانى، نظارت مداوم بر تهديد ورديد و به كار گيرى راهبردهاى مقابلهاى ناساز كار را به دنبال

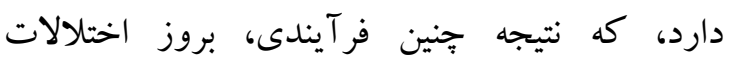

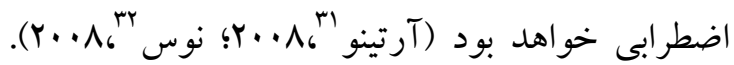
بنابراين مىتوان كفت تقويت فراشناخت (دانش فراشناختى و كنترل كنندهاى فراشناختى) منجر به به شكل كيرى سبك تفكر فراشناختى مى شود. سبك ونى تفكر فراشناختى، قابليت هاى شناختى و عملكرد فرد را تقويت نموده و از آسيب هاى روانشناختى بيشخيرى

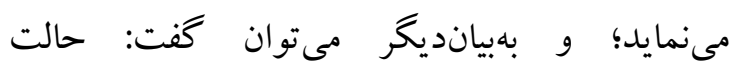
فراشناختى داراى نقش بازدارنده در فرايند نخرانى است. برعكس جنانجه باورهاى فراشناختى معطوف به به به نكرانى افزايش يابد، منجر به شكل گيرى سبك تفك باوره عينى شده و بروز آسيبهاى روانشناختى را به دنبال خو اهد داشت؛ بنابراين نتايج اين يثوهش همسو با نتايج تحقيقات ييشين، نشان مىدهد كه در نظر گرفتن عدم تحمل بلاتكليفى و باورهاى فراشناختى در برنامههاى

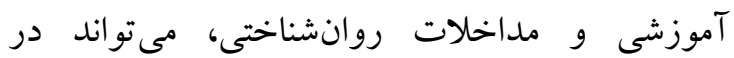
بيشخيرى از اختلالات هيجانى، كاهش و درمان آنها

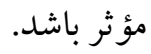

از محدوديتهاى اين يُزوهش حاضر مىتوان به ابزارهاى خود گزارش دهى اشاره كرد كه مىتواند نتايج را تحت تأثير قرار دهد. همجنين روش روش نمونه گيرى بثزوهش در دسترس بود و همجنين نقش جنسيت در اين ائزوهش در نظر كرفته نشده است.

\footnotetext{
${ }^{31}$ Artino

${ }^{32}$ Knouse
} 
Corcoran KM, Segal ZV.(2008). Metacognition in depressive and anxiety disorder. Cument directions. Inter. J of Cogn Ther, 1(1): 33-44

Davey CL, Wells A.(2006). Worry and its Psychological Disorder, Theory, Assessment and Treatment, Copyright by Wiley \& Sons Ltd; PP: 3-121.

Dugas MJ, Hedayati M, Karavidas A, Buhr K, Francis K, Phillips NA.(2005). Intolerance of uncertainty and information processing: Evidence of biased recall and interpretations. Cognit Ther Res; 29(1): 57-70.

Dugas MJ, RobichaudM.(2007).CognitiveBehavioral Treatment for GeneralizedAnxiety Disorder. From Science to practice.New York: Routledge.

Dugas MJ, schewartz A, Francis K.(2004) Intolerance of uncertainty, Worry, and depression. Cogn Ther Res; 28: 835-842.

Dupuy,J.,\&Ladouceur,R.(2008).Cognitive processes of generalized anxiety disorder in comorbid generalized anxiety disorder and major depressive disorder. Journal of Anxiety Disorders,22, 505-514

Fahimi S.(2012). Attentional bias toward signs of intolerance of uncertainty in information processing process of people with generalized anxiety disorder (GAD) [Thesis]. Tabriz: University of Tabriz.

Francis, K. and Dugas, M. (2004). Assessing Positive Beliefs about Worry: Validation of a Structured Interview. Personality and Individual Differences. 37, (2), 405-415.

Freeston MH, Rheauma J, Litarte H, Dugas MJ, Ladouceur R.(1994). Why Do People Worry?. Personal Individ Differ. 17: 791-802.

Hong, R. Y. (2007). Worry and rumination: Differential associations with anxious and depressive symptoms and coping behavior. Behaviour Research and Therapy, 45(4), 277-290.

Hughes, M. E., Alloy, L. B., \& Cogswell, A. (2008). Repetitive thought in psychopathology: The relation of rumination and worry to depression and anxiety symptoms. Joumal of Cognitive Psychotherapy, 22 (1), 271-289.

Knouse, L. E. (2008). AD/HD, Meta memory, and Self- Regulation in context, unpublished Doctoral Dissertation, faculty of The Graduate school, Greensboro University
Koemer N, Dugas MJ.(2008). An investigation of appraisals in individuals vulnerable to excessive worry: The role of intolerance of uncertainty. Cognit TherRes; 32(5): 619-38.

Mahmood-Aliloo M, Shahjoyi T, Hashemi Z(2010). comparision Intolerance of uncertainty, cognitive avoidance, negative attitude to problem and positive believes about worry between individual with General Anxiety Disorder and normal individuals. Tabriz $\mathbf{J}$ Psychol; 20: 20-32. [Persian].

Muris, P., Roelofs, J., Meesters, C., \& Boomsma, P. (2004). Rumination and worry in nonclinical adolescents. Cognitive Therapy and Research, 28(1), 539-554.

Parker, G.A. \& Roy,K.L.(2001).Adolescent depression: Areview. Australian \& NewZealland J of psychology.35(5):572-580.

Scarpa A, Wilson LC, Wells AO, Patriquin MA, Tanaka A.(2009). Thought control strategies as mediators of trauma symptoms in young women with histories of child sexual abuse. Behavior Research and Therapy;47:809-13.

Shirinzadeh, S.(2006). The comparison of meta cognitive beliefs and responsibility in patients with obsessive-compulsive,generalized anxiety disorder and normal persons. Master of art thesis.shiraz uni; 14(1): 46-55. [Persian].

Sugiura Y.( 2007). Responsibility to continue and worrying: evidence of incremental validity. Behav Res Ther, 45: 1619-1623.

van der Heiden $\mathrm{C}$, Melchoir $\mathrm{K}$, Muris $\mathrm{P}$, Bouwmeester $\mathrm{S}$, Bos $\mathrm{AE}$, van der Molen HT.(2010).A hierarchical model for the relationships between general and specific vulnerability factors and symptom levels of generalized anxiety disorder. J Anxiety Disord; 24(2): 284-9.

Wells A.(1999). A metacognitive model and therapy for generalized anxiety disorder, Clin psy and Psy Ther:; 6: 86-96.

Wells A.(2000). Emotional disorders and Metacognition: Innovative Cognitive Therapy, JohnWiley\& SonsLTD; PP: 3-54.

Wells, A. (1995). Meta-Cognition and Worry: a Cognitive Model of Generalised Anxiety Disorder. Behavioural and Cognitive Psychotherapy, 23, (3), 301-320.

Wells, A. and Papageorgiou, C. (1998). Relationships between Worry ObsessiveCompulsive 
Symptoms and MetaCognition Beliefs. Behaviour Research and Therapy. 36, (9), 899913.

Wells, A. Carter, K. (1999). Preliminary Tests of a Cognitive Model of Generalized Anxiety Disorder. Behaviour Research and Therapy. 37, (6), 585-594.
Wells, A. Carter, K. (1999). Preliminary Tests of a Cognitive Model of Generalized Anxiety Disorder. Behaviour Research and Therapy. 37 , (6), 585-594.

Wells, A., \& Cartwright-Hatton, S. (2004). A short form of the Metacognitions Questionnaire: Properties of the MCQ-30. Behavior Research and Therapy, 42, 385-396. 